the extreme north, where the elements here absorbed belonged to some of the best Slav blood-Serbs and Montenegrins. But the plain and often even repulsive features met with in some of the central districts would seem to point at fusion with the Ugrian or Volga Finn Bulgarians, whose beadquarters were at Okhrida, and who at that time (8th and 9 th centuries) had not yet been Slavonised. Nevertheless, the Albanians are on the whole a fine and even a handsome race, with long head, oval face, long thin nose, rather high cheek bones, small eyes, generally grey or blue, hair often fair or light brown, long neck, broad chest, slim and upright figures. But descriptions of course vary with the experiences of the observer. Thus while Pouqueville speaks rather of black eyes, others describe the Toshks as essentially a blue-eyed and light-haired race. In general the purest type is found in the district between the Shkumbi and Voyussa, where Kamardas says that the language also is spoken in the greatest purity. North and south of this district both people and language are more or less intermingled with Slav and Hellenic elements respectively.

\section{A. H. KEANE}

\section{REPORT OF THIE BRITISH MUSEUM}

THE Parliamentary Report of the Trustees of the British Museum, which has been lately issued, tells us that during the past year much progress has been made in arrangements for removal of the natural history collections, and in preparations for their reception in the new buildings designed for them at South Kensington. New cases and fittings have been provided and erected for the departments of botany and mineralogy, and in part for that of geology; and the transference of these three collections to the new museum will probably be effected in the course of the present year. The galleries vacated by these collections will be at once made use of for the exhibition of objects of archacological interest which have been accumulating for many years, and from want of space have been stored away in imperfectly-lighted rooms in the basement of the British Museum.

The whole of the zoological and geological portions of the India Museum at South Kensington, together with the friezes from the Amravati Tope and other remains of ancient sculpture, have been made over by the Secretary of State and Council of India to the Trustees of the British Museum. The sculpture will be exhibited in the Museum ; the zoological and other collections have been removed to the New Natural History Museum at South Kensington.

Turning to Prof. Owen's special report on the departments of natural history, we are told that part of the work during the past ycar has been that of the preparation of the collections for the pending transfer to South Kensington.

In the department of zoology Dr. Günther informs us that not less than $45,88 \mathrm{I}$ specimens have been added to the several parts of the collection; of this, however, more than half is attributable to the collection of exotic butterflies, bequeathed to the nation by the Iate William Chapman Hewitson. This is one of the most extensive and valuable collections of this group of animals that has ever been formed; it consists of 24,624 specimens referable to 5,795 species, many of which have been described by the testator in his "Exotic Butterflies," "Diurnal Lepidoptera," and other works. The collection is in a perfect state of arrangement and preservation, and by Mr. Hewitson's direction a catalogue of its contents has been prepared and printed at the expense of his estate. The testator attached to this bequest the condition that the collection should be called the "Hewitson Collection," and should be kept in good order, preservation, and condition, and in the same cabinets, and in the same order and arrangement, and under the same nomenclature as they should be at the time of his decease, until the expiration of twenty-one years from that time.

Another important addition to the national collection of insects made during the last parliamentary year was the Wollaston collection of St. Helena Lepidoptera, consisting of 364 specimens, and including types of thirty-eight species, collected and described by Mrs. Vernon Wollaston. This must be regarded as one of the most important acquisitions of last year, as the accurate and perfect knowledge of the fauna and flora of so isolated a locality as St. Helena at a given period will enable future investigators to determine exactly the changes which are taking place in oceanic islands, not only with regard to the composition of their fauna and flora, but also with regard to the specific characters of the animals and plants imported into them.

Four additions have been made to the well-known series of zoological catalogues in 1879 , namely, the fourth volume of Mr. Sharpe's "Catalogue of Birds"; an octavo volume by $\mathrm{Mr}, \mathrm{C}$. $\mathrm{O}$. Waterhouse, containing descriptions of typical specimens of coleoptera, illustrated by coloured plates; a volume containing descriptions of a number of new species of hymenoptera by the late Mr. Frederick Smith, which the lamented author left nearly ready for publication at the time of his death; and the third volume of Mr. Butler's "Illustrations of Typical Specimens of Lepidoptera heterocera."

Mr. Waterhouse's report on the Geological Department and Mr. Story Maskelyne's on that of Mineralogy succeed that of Dr. Günther, but we observe nothing of very special interest contained in them. Mr. Carruthers' report on Botany records an important addition to that department in the shape of the extensive herbarium of the late John Miers, F.R.S., \&c., the distinguished botanist, which he bequeathed to the Trustees. It contains the types of the species described in his numerous systematic works and memoirs, as far as they were in his own possession, together with an extensive series of South American plants from various collectors, and many valuable collections from other regions of the world. Besides the plants Mr. John W. Miers has presented to the department the large scries of original drawings made by his father from the living plants in South America and from dissections of plants in later years,

\section{MARCEL DEPREZ'S GALVANOMETER FOR STRONG CURRENTS}

PRACTICAL electricians have laboured up to the present time under a considerable difficulty in attempting to measure the strength of very powerful electric currents, such as are, for example, employed in the production of the electric light. There has been no simple instrument suited to the rapid direct measurement of the strength of such currents, much less one that would measure any fluctuations of short duration. Ordinary galvanometers have not been equal to the task, being adapted for a different class of work, usually of too high a resistance to be safely introduced into the circuit, and in general too leisurely in their movements to afford indications of any rapid fluctuations.

Although the current furnished by a good dynamoelectric machine, such as those of Gramme, Siemens and Brush, may for most practical purposes be considered both continuous and uniform, the construction of these instruments could hardly leave any doubt on a prior: grounds that the current really consists of a number of successive impulses, which, although they may, as it were, run into one another and yield a continuous current, yet cause the strength of the current to be continually increasing and diminishing in rapid alternations; and indeed the telephone shows clearly that this is the case, for a low humming sound is heard in that instrument when its 